Chapman University

Chapman University Digital Commons

Food Science Faculty Articles and Research

Science and Technology Faculty Articles and

Research

8-24-2017

\title{
Chlorogenic Acid Oxidation-Induced Greening of Sunflower Butter Cookies as a Function of Different Sweeteners and Storage Conditions
}

\author{
Sihui Liang \\ Chapman University \\ Lilian Were \\ Chapman University, were@chapman.edu
}

Follow this and additional works at: https://digitalcommons.chapman.edu/food_science_articles

Part of the Food Chemistry Commons, and the Other Food Science Commons

\section{Recommended Citation}

Liang, S., Were, L., Chlorogenic Acid Oxidation-Induced Greening of Sunflower Butter Cookies as a Function of Different Sweeteners and Storage Conditions, Food Chemistry 241 (2017), 135-142. doi: 10.1016/j.foodchem.2017.08.084

This Article is brought to you for free and open access by the Science and Technology Faculty Articles and Research at Chapman University Digital Commons. It has been accepted for inclusion in Food Science Faculty Articles and Research by an authorized administrator of Chapman University

Digital Commons. For more information, please contact laughtin@chapman.edu. 


\section{Chlorogenic Acid Oxidation-Induced Greening of Sunflower Butter Cookies as a Function of Different Sweeteners and Storage Conditions}

\section{Comments}

NOTICE: this is the author's version of a work that was accepted for publication in Food Chemistry. Changes resulting from the publishing process, such as peer review, editing, corrections, structural formatting, and other quality control mechanisms may not be reflected in this document. Changes may have been made to this work since it was submitted for publication. A definitive version was subsequently published in Food

Chemistry, volume 241, in 2017. DOI: 10.1016/j.foodchem.2017.08.084

The Creative Commons license below applies only to this version of the article.

\section{Creative Commons License}

\section{(c) 1 (1) 90}

This work is licensed under a Creative Commons Attribution-Noncommercial-No Derivative Works 4.0 License.

\section{Copyright}

Elsevier 


\section{Accepted Manuscript}

Chlorogenic Acid Oxidation-Induced Greening of Sunflower Butter Cookies as a Function of Different Sweeteners and Storage Conditions

Sihui Liang, Lilian Were

PII:

S0308-8146(17)31419-X

DOI: http://dx.doi.org/10.1016/j.foodchem.2017.08.084

Reference: FOCH 21633

To appear in:

\section{Food Chemistry}

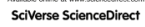

Received Date: $\quad 12$ April 2017

Revised Date: $\quad 17$ July 2017

Accepted Date: 23 August 2017

Please cite this article as: Liang, S., Were, L., Chlorogenic Acid Oxidation-Induced Greening of Sunflower Butter Cookies as a Function of Different Sweeteners and Storage Conditions, Food Chemistry (2017), doi: http:// dx.doi.org/10.1016/j.foodchem.2017.08.084

This is a PDF file of an unedited manuscript that has been accepted for publication. As a service to our customers we are providing this early version of the manuscript. The manuscript will undergo copyediting, typesetting, and review of the resulting proof before it is published in its final form. Please note that during the production process errors may be discovered which could affect the content, and all legal disclaimers that apply to the journal pertain. 
Chlorogenic Acid Oxidation-Induced Greening of Sunflower Butter Cookies as a Function of Different Sweeteners and Storage Conditions

\section{Names of Authors}

Sihui Liang, and Lilian Were*

\section{Author Affiliation}

Food Science Program, Schmid College of Science and Technology, Chapman University, One University Drive, Orange, CA 92866, USA

*Contact information for Corresponding Author

Lilian Were, Ph.D.

Chapman University

Phone: 714-744-7895

Fax: 714-289-2041

E-mail: were@chapman.edu 


\section{Highlights:}

- Sweeteners with higher moisture and/or pH enhanced greening in cookies

- Storage at higher relative humidity resulted in higher surface greening

- Chlorogenic acid-lysine adduct content was inversely correlated to greening reactants

- Lowering the $\mathrm{pH}$, moisture and $\mathrm{a}_{\mathrm{w}}$ would inhibit greening when it is not desired. 


\section{ABSTRACT}

Sunflower butter use as an allergen-free alternative to tree and legume nut butter in baking is limited by chlorogenic acid induced greening that occurs at alkaline $\mathrm{pH}$. Limited information is available on controlling this greening in a food matrix. This study examined how different liquid sweeteners and relative humidity influenced greening of sunflower butter cookies. Doughs had similar initial $\mathrm{pH}(7.52-7.66)$ which increased to 8.44-9.13 after baking as ranked: xylitol>maple syrup $>$ corn syrup $>$ honey $>$ agave syrup. Cookies made with maple syrup had the highest moisture and greening corresponding with lowest free chlorogenic acid. The $\%$ greening followed the same trend as greening intensity, and was positively correlated $(\mathrm{r}=0.9101)$ with chlorogeniclysine adduct content. Our findings provide an ingredient solution to controlling greening, as results demonstrate that greening can be promoted with high relative humidity storage, and use of high moisture and $\mathrm{pH}$ ingredients. Unwanted greening can be inhibited by simply changing the liquid sweetener.

Keywords: chlorogenic acid, greening, moisture, $\mathrm{pH}$, sunflower butter

Chemical Compounds Studied in This Article

Chlorogenic acid (PubChem CID: 1794427); L-lysine (PubChem CID: 5962) 


\section{Introduction}

Sunflower seed butter can act as an alternative to legume and tree nut based plant butters, which are members of the "big 8" allergens affecting an estimated 0.6-1.3 and 0.4-0.6\% people in USA who suffer from peanut and tree nut allergies respectively (FDA, 2016; Peabody, 2016). Sunflower nut butter contains a higher phenolic content $(1-5 \%)$ than other nut butters. Of the total phenols, 50-70\% is chlorogenic acid (CGA), a substrate in both browning and greening reactions with sunflower protein during aqueous processing or under alkaline conditions (Bekedam, Schols, Van Boekel, \& Smit, 2008; Weisz, Kammerer, \& Carle, 2009; Yabuta, Koizumi, Namiki, Hida, \& Namiki, 2001).

Use of sunflower seed butter can cause bitterness and firmness, and it is difficult to spread compared to peanut butter, which can make it less acceptable to consumers (Lima \& Guraya, 2005). Due to the bitterness, sweetened versions of sunflower butter are commercially available (NPI, 2014). These sweeteners differ in pH, moisture, and phenolic content and this could affect the visual appeal of sunflower butter bakery products. For instance, the higher $\mathrm{pH}$ of maple syrup compared to honey could impact post-baking color reactions (Ball, 2007) such as the greening reaction in sunflower seed based products. Texture and taste are challenges the industry has overcome, but the green color remains a problem when using sunflower butter in bakery applications when greening is considered undesirable. The oxidation product of CGA dimer: $o$-quinone reacts with amino acids and side chains of proteins to form green trihydroxy benzacridine (TBA) derivatives under alkaline conditions. Yabuta et al. (2001) showed that $\mathrm{pH}$ influences the binding of CGA to sunflower protein. Increasing $\mathrm{pH}$ from 5 to 9 results in a color change from yellow to blue-green. The role of $\mathrm{pH}$ and moisture in polyphenoloxidase induced 
greening has been determined (Vaintraub \& Kratch, 1989), however, the role of moisture in nonenzymatic greening reactions has not been fully investigated in a food matrix.

\section{Materials and methods}

\subsection{Cookie Formulation and Experimental Design}

Two batches of sunflower butter cookie dough with different sweeteners were prepared separately and baked at $149{ }^{\circ} \mathrm{C}\left(300{ }^{\circ} \mathrm{F}\right)$. After mixing flour (39.7\%), baking soda $(0.6 \%)$ and salt $(0.6 \%)$, egg $(13 \%)$, sweeteners $(21.2 \%)$, sunflower butter $(24.3 \%)$ and vanilla extract $(0.6 \%)$ were then added. The doughs $(0.5 \pm 0.2 \mathrm{~cm}$ thick $)$ were cut with a $4.5 \mathrm{~cm}$ diameter cutter. Baking was carried out using a convection oven (JA12SL, Doyon, Inc. Saint-Côme-Linière, Canada) at $149{ }^{\circ} \mathrm{C}$ for $7 \mathrm{~min}$, with the temperature monitored using a thermocouple. Three desiccator cabinets (Fisherbrand ${ }^{\mathrm{TM}}$ ) containing $\mathrm{NaOH}, \mathrm{K}_{2} \mathrm{CO}_{3}$, and $\left(\mathrm{NH}_{4}\right)_{2} \mathrm{SO}_{4}$ solutions were prepared, and had $\mathrm{RH}$ of 75,79 , and $84 \% \mathrm{RH}$ respectively measured using a $\operatorname{LogTag}^{\circledR}$ humidity and temperature recorder.

\section{2. $\mathrm{pH}$ and ${ }^{\circ}$ Brix Index of Sweeteners}

A xylitol solution was prepared by dissolving xylitol granules $(4.4 \mathrm{~g})$ in $5 \mathrm{ml}$ nanofiltered water at $75^{\circ} \mathrm{C}(88 \% \mathrm{w} / \mathrm{v})$ to obtain a similar moisture content as honey. The same ratio of sweeteners in cookies were used to make sweetener-water solutions by weighing $0.1 \mathrm{~g}$ of the liquid sweeteners and adding $5 \mathrm{ml}$ nano filtered water. Sweetener solutions $(2 \% \mathrm{w} / \mathrm{v})$ were vortexed for $30 \mathrm{~s}$ and then incubated at room temperature for $3 \mathrm{~h}$ on a shaker (Rocker II, 260350, Boekel Industries, Inc. PA) at a speed of $1.5^{*} \mathrm{~g}$. The $\mathrm{pH}$ was tested after incubation using a LabQuest $2^{\circledR} \mathrm{pH}$ meter (Vernier Software \& Technology, OR, USA). The ${ }^{\circ}$ Brix index of $0.3 \mathrm{ml}$ 
of each sweetener was tested using a PAL- $\alpha$, ATAGO refractometer (Nova Tech International, Inc. TX, USA).

\subsection{Physical Tests of Cookie and Dough}

\subsection{1. $p H$ and Water Activity $\left(a_{w}\right)$}

Dough and cookie sample solutions $(10 \%, \mathrm{w} / \mathrm{v})$ were prepared with nano filtered water (Miller, Graf, \& Hoseney, 1994), and incubated for $3 \mathrm{~h}$ on a shaker at a speed of $1.5^{*} \mathrm{~g}$. After incubation, cookie and dough samples were centrifuged (AccuSpin 1R-75003449, Thermo Fisher Scientific, Inc. CA) at $9000^{*} \mathrm{~g}$ at $4{ }^{\circ} \mathrm{C}$ for $15 \mathrm{~min}$ and the supernatant was used for testing (AACCI, 1999a). Water activity of cookies was measured right after each color testing (section 2.5) using a water activity meter (Model 3ET, Aqua Lab Technologies, Inc. CA, USA) according to manufacturer's instructions.

\subsubsection{Moisture Content and Spread Factor}

Moisture content was determined using a vacuum oven as outlined in AOAC method 925.09 (AOAC, 2005) with modifications. Samples (3 g) were placed into pre-dried aluminum pans and put in a vacuum oven (Model 281, Thermo Fisher Scientific, Inc. CA), maintained at 60 ${ }^{\circ} \mathrm{C}$ and pressure of $-70 \mathrm{kPa}$ for $24 \mathrm{~h}$. After drying, samples were cooled in a desiccator for $6 \mathrm{~h}$. The weights of samples were recorded before and after drying.

The spread factor was measured following AACCI Method 10-50.05 (1999b) by randomly selecting 6 cookies (three from each batch). A vernier caliper (Mecanic Type 6911. KWB, Inc. Switzerland) was used to measure the width and thickness of cookies. The spread factor was calculated by dividing the width by the thickness of the cookies. 


\subsection{Protein Content}

Supernatants $(250 \mu \mathrm{l})$ from section 2.3 were prepared following the DNPH assay as outlined by Hawkins, Morgan, and Davies (2009), and protein content was determined at $280 \mathrm{~nm}$ using a spectrophotometer (Vernier Software \& Technology, OR, USA).

\subsection{Color Changes}

Color changes were measured after $0.25,1,4,7,11$, and $24 \mathrm{~h}$ post-baking under uncovered storage and 1, 4, and 7 days after three relative humidity/RH conditions $(75,79$, and 84\%). Greening changes were measured using a spectrophotometer (CM-2500d, Konica Minolta, Inc. Japan) and analyzed using SpectraMagic NX color data software. The spectrophotometer aperture size was $8 \mathrm{~mm}$ and the scan number was twice per sample. The illuminant was $\mathrm{D}_{65}$ and the radius of illumination area was $8 \mathrm{~mm}$, with an observation angle of $10^{\circ}$. Data was collected as $\mathrm{L}^{*}$ [darkness to lightness $\left.(0-100)\right], \mathrm{a}^{*}$ [greenness $\left(-\mathrm{a}^{*}\right)$ to redness $\left.\left(\mathrm{a}^{*}\right)\right]$, and $\mathrm{b}^{*}$ [blueness $\left(-\mathrm{b}^{*}\right)$ to yellowness $\left.\left(b^{*}\right)\right]$. Two different surface locations (upper and bottom) of whole cookie samples were placed under a $2 \mathrm{~mm}$ cylinder probe and $\mathrm{L}^{*}, \mathrm{a}^{*}$, and $\mathrm{b}^{*}$ was recorded. The cookie samples were then sliced to measure internal greening.

The percent internal greening of cookies was measured using an image analyzer CVX422A and CA-H1DB VisionDatabase Ver 1.2 (Keyence America, Corp. CA, USA). Samples were placed under a camera with $2 \mathrm{M}$ pixels with 16 speed color change-coupled devices (CAHX200C) and the image was captured for analysis. The distance from the camera to cookie was $28 \mathrm{~cm}$. The image size was set as $1600 \times 1200$, shutter speed was $1 / 30$, and the sensitivity was 6.3 . The binary luminosity was 180 for greening and 85 for browning. The radius of the cookies averaged $2.3 \mathrm{~cm}$ and the preset area on the image was kept at a radius of $1.5 \mathrm{~cm}$. The mouse 
pointer was used for selecting green areas on cookies. The percent greening was calculated by dividing the green area by the whole selected cookie area (Ishak \& Hudzari, 2010).

Cookie samples (0.6 g in $20 \mathrm{ml})$ were then homogenized (Multi-prep Homogenizer, PRO Scientific Inc., Oxford, CT, USA) at $1.3 \times 10^{3 *} \mathrm{~g}$ for $1 \mathrm{~min}$. The solutions were filtered using Double Rings ${ }^{\circledR}$ No. 102 filter papers and then through a $0.45 \mu \mathrm{m}$ nylon filter. Green and brown color of solutions were determined using a SpectroVis ${ }^{\circledR}$ Plus spectrophotometer (Vernier Software \& Technology, OR, USA) at $\lambda_{680}$ and $\lambda_{420}$, respectively.

\subsection{Chlorogenic Acid and Trihydroxy Benzacridine Derivatives Content}

Dough or cookies $(0.9 \mathrm{~g})$ were dissolved in $30 \mathrm{ml}$ HPLC water. After homogenization (Multi-prep Homogenizer, PRO Scientific Inc., Oxford, CT, USA) at $1.3 \times 10^{3} \mathrm{~g}$ for $1 \mathrm{~min}$, sample solutions were centrifuged at $9 \times 10^{3} * \mathrm{~g}$ (AccuSpin 1R-75003449, Thermo Fisher Scientific, Inc. CA, USA) for $20 \mathrm{~min}$ at $4{ }^{\circ} \mathrm{C}$. The supernatant was first filtered through Double Rings $^{\circledR}$ No. 102 filter paper and then filtered through a $0.45 \mu$ m nylon filter for HPLC analysis. Chlorogenic acid purchased from Sigma-Aldrich (Saint Louis, MO, USA) was used to make a standard curve $(0-0.060 \mathrm{mg} / \mathrm{ml}$ in HPLC water).

Chlorogenic acid quantification was carried out on an Agilent 1100 series HPLC (Agilent Technologies, Inc. Santa Clara, CA, USA) with a Phenomenex ${ }^{\circledR}$ Luna $5 \mu$ C8 (2) $100 \AA$ (150 x 2 $\mathrm{mm}, 1.5 \mu \mathrm{m}$ particle size) column using a modified method from Jully, Toto \& Were (2016). The $\mathrm{UV}-\mathrm{Vis}$ detector was operating at $320 \mathrm{~nm}$. Mobile phases were $0.1 \%$ glacial acetic acid/water (A) and $0.1 \%$ glacial acetic acid/acetonitrile (B). The gradient used was 0 min, $6.0 \% \mathrm{~B} ; 2$ min, 7.0\% B; $2.5 \min , 7.2 \% \mathrm{~B} ; 3 \min , 7.3 \% \mathrm{~B} ; 4 \mathrm{~min}, 7.4 \% \mathrm{~B} ; 5 \mathrm{~min}, 7.5 \% \mathrm{~B} ; 5.5 \mathrm{~min}, 7.7 \% ; 6$ $\min , 10 \% \mathrm{~B} ; 7 \mathrm{~min}, 6.0 \% \mathrm{~B} ; 8 \mathrm{~min} 6.0 \% \mathrm{~B}$ at a flow rate of $0.8 \mathrm{ml} / \mathrm{min}$ with column temperature at $30{ }^{\circ} \mathrm{C}$. 
Chlorogenic acid-lysine standard was prepared by mixing $5 \mathrm{ml}$ of $112 \mathrm{mM}$ lysine with 5 $\mathrm{ml}$ of $28 \mathrm{mM}$ CGA solutions. The pH of CGA-lysine solution was adjusted to 9.0 and stirred for $20 \mathrm{~h}$ at room temperature for greening reaction (Bongartz, Brandt, Gehrmann, Zimmermann, Schulze-Kaysers, \& Schieber, 2016; Prigent, Voragen, Li, Visser, van Koningsveld, \& Gruppen, 2008). The original adduct solution was diluted $1: 2,1: 4,1: 6,1: 8$ and 1:10 (v:v) for quantifying CGA-lysine adducts. The CGA control solution was diluted 1:1 with HPLC water, and was also stirred for $20 \mathrm{~h}$ without adjusting $\mathrm{pH}$. Adducts were determined using a Phenomenex ${ }^{\circledR}$ Luna $5 \mu$ C8 (2) $100 \AA$ (150 x 2 mm, $1.5 \mu \mathrm{m}$ particle size) column with LC/MS (LC: Ultimate 3000 series, Thermo Fisher Scientific, Inc. CA; MS: Impact II, Bruker, CA, USA) according to the method of Bongartz et al. (2016) with modification: the gradient program was 0-20 min, 2\% B; 20-20.5 $\min , 17.7 \% \mathrm{~B} ; 20.5-22.5 \min , 100 \% \mathrm{~B}$ and 22.5-36 min 2\% B. MS detection used Electrospray Ionization source (ESI) with positive polarity, while the end plate offset and capillary voltage was kept at -500 and $4500 \mathrm{~V}$, respectively. The ion and collision energy were 4.0 and $25.0 \mathrm{eV}$. For ion cooler, the transfer and prepulse storage time were 220.0 and $20.0 \mu$ s, respectively. The dry gas temperature was kept at $180{ }^{\circ} \mathrm{C}$ with a flow rate of $41 / \mathrm{min}$. The UV-Vis detector was monitored at 280, 320, and $631 \mathrm{~nm}$. The mass spectra of the column eluate for positive ion ranged from $m / z 50$ to 1200 .

\subsection{Statistical Analysis}

The effect of liquid sweetener type, storage conditions, storage time and their interactions were evaluated in a mixed model two- and three-way analysis of variance (ANOVA): two fixed effects (sweeteners and storage conditions) as variables were repeated at 9 different time points. Where a significant effect of treatment was detected, the Student T-test was used to determine the levels of significance between dependent variables and two and three-way interactions of independent variables. All values were reported as the mean \pm standard deviation from two 
batches of dough made on the same day. Differences were considered significant when $P<0.05$. Correlations between variables were also calculated using Statistics Analysis Software (SAS institute Inc. NC, USA).

\section{Results and Discussion}

\subsection{Compositional and Physical Analysis of Sweeteners, Cookies and Dough}

\subsection{1. ${ }^{\circ}$ Brix and $\mathrm{pH}$ of Sweeteners}

The ${ }^{\circ}$ Brix index (soluble solid content) of each liquid sweetener ( $2 \%$ solution) were ranked as: honey (81.23)>corn syrup (77.48)>agave syrup (76.85)>xylitol (75.05)>maple syrup (65.80).

Honey solutions had significantly lower $\mathrm{pH}(P<0.05)$, while maple syrup solutions had the highest $\mathrm{pH}$ (Table 1). The lower $\mathrm{pH}$ of honey is attributed to higher organic acids $(0.57 \%$, formed during fermentation from nectar into honey where glucose is converted to hydrogen peroxide and gluconic acid by glucose oxidase, in addition to having formic, citric, acetic, and malic acids (Silva, Gauche, Gonzaga, Costa, \& Fett, 2016).

\subsection{2. $\mathrm{pH}$, Water Activity $\left(a_{w}\right)$, Moisture and Spread Factor of Dough and Cookies}

The $\mathrm{pH}$ of $10 \%$ dough solutions ranged from 7.52-7.66. Dough made from honey had the lowest $\mathrm{pH}$ of 7.52 compared to other dough solutions. After baking, $\mathrm{pH}$ of all cookies increased (Table 1). For instance, $\mathrm{pH}$ of cookie solutions made with maple syrup and xylitol increased from 7.57 and 7.66 to 8.99 and 9.13, respectively. Higher $\mathrm{pH}$ of cookies after baking was possibly related to the sodium bicarbonate's leavening action during baking to produce sodium carbonate, which is more alkaline than sodium bicarbonate (Gokmen, Acar, Serpen, \& Morales, 2008). The pH of cookie solutions made with xylitol was highest, followed by maple syrup, corn syrup, honey and agave syrup, correlated with the initial $\mathrm{pH}$ in sweeteners (Table 1). 
Cookies made with maple syrup had the highest $\mathrm{a}_{\mathrm{w}}$, while cookies made with xylitol had the lowest $\mathrm{a}_{\mathrm{w}}$ after storage (Table 2; $\mathrm{P}<0.05$ ), consistent with differences in moisture content of the sweeteners (Table 1). As expected the $\mathrm{a}_{\mathrm{w}}$ was inversely related to ${ }^{\circ}$ Brix with a correlation coefficient of -0.6229 .

Cookies made with maple syrup had the highest moisture content $(P<0.05)$. The moisture content of cookies was positively correlated $(r=0.8701)$ with the moisture content in sweeteners (Table 1; Fradinho, Cristiana Nunes, \& Raymundo, 2015). The difference in moisture and humectancy of sugars affected the water loss during baking (Cauvain \& Young, 2008), as observed in cookies made with honey which had the lowest percent moisture loss (26\%) compared to water loss in other cookies that ranged from $30-42 \%$.

The spread factor (SF) of cookies was negatively correlated ( $\mathrm{r}=-0.6780)$ with moisture content of the different sweeteners (Fradinho, Cristiana Nunes, \& Raymundo, 2015). The SF of dough was similar except for dough made with maple syrup which had the lowest SF. The lowest SF of maple syrup dough was due to the highest moisture content of maple syrup, which made the dough easier to spread (Suas, 2009). After baking, the SF of cookies decreased possibly due to the leavening effect of baking soda (Serna-Saldivar, 2012; Zhang, Nishizu, Kishigami, Kato, \& Goto, 2013). During baking, the moisture content affected SF, because when moisture content is low, the transition from rubbery to glassy phase occurs which then stops the shrinkage of dough during baking (Table 1).

\subsection{Hunter $L^{*} a^{*} b^{*}$ and Image Analysis}

Cookies made with maple syrup and xylitol both turned green within $4 \mathrm{~h}$ when left uncovered at room temperature storage, whereas cookies made with other sweeteners did not show surface greening until after $24 \mathrm{~h}$ (Fig. 1a-b). Internal greening commenced in cookies made with maple syrup and xylitol right after baking (Fig. 1c). Higher greening in cookies made with 
xylitol and maple syrup was attributed to these sweeteners both having the highest initial $\mathrm{pH}$ of the sweeteners tested, in addition to highest initial moisture in maple syrup (Table 1). In contrast, the delayed greening that occurred after $4 \mathrm{~h}$ in cookies made using honey and agave syrup, was attributed to lower initial $\mathrm{pH}$ and moisture content in these cookies. Cookies made with agave syrup greened faster than cookies made with honey $(1.7$ and $0.4 \%$ per hour during $24 \mathrm{~h}$ of uncovered storage, respectively), despite having similar $\mathrm{pH}$ after $24 \mathrm{~h}$, which indicated initial moisture content of sweeteners affected the greening reaction more than $\mathrm{pH}$ during storage (Table 1, Fig. 1d).

The $\%$ internal greening in cookies that were stored uncovered at room temperature increased with time during $24 \mathrm{~h}$ due to continual CGA-amino acid reactions (Fig. 1d, Yabuta, et al., 2001).

Cookies in the chambers with highest RH (84\%) had higher greening, due to the higher moisture in the environment (Yabuta, et al., 2001). Within each chamber, cookies made with maple syrup and xylitol showed the highest greening, consistent with results in uncovered cookie samples, where sweeteners with higher initial moisture and/or pH were more green (Fig.1, Fig. S1 - supplementary material). Under alkaline conditions, the hydroxyl groups on the $o$-quinone loose protons and the negatively charged oxygen atoms oxidize easily which then react with amino groups to form the green pigments in sunflower butter cookies (Yabuta, et al., 2001). Besides storage conditions, time also affected color. The increased a* value after 4 and 7 days in some cookies made with maple syrup and xylitol was caused by the continued greening reaction which resulted in green to blue-green pigments formed (Yabuta, et al., 2001), which resulted in lower $b^{*}$ but higher $a^{*}$ value. The $\%$ internal greening of cookies shown in Fig. 1, followed a 
similar trend to that of the greening intensity, where cookies made with maple syrup showed the highest \% greening followed by cookies made with xylitol and corn syrup.

In summary, the different sweeteners, storage conditions, storage time, and interaction between sweeteners and time had a significant effect on greening ( $P \leq 0.0001$, F test; Table 3$)$. There was also a significant interaction $(P<0.0001)$ between liquid sweeteners used and storage time with greening intensity, indicating the use of different sweeteners and storage time can both be manipulated to alter greening during storage. Although different RH conditions significantly affected the greening intensity, their interaction with time and different sweeteners had no effect on greening intensity (Table 3).

\subsection{Changes in Color Reactants and Products in Sunflower Dough and Cookies}

\subsubsection{Protein Content}

Dough and cookies made with corn syrup had the highest free protein content, possibly due to less color reactions (Maillard and greening combined) occurring during dough preparation and baking (Table 1). Corn syrup has less reducing sugar compared to honey and agave sryup (St-Pierre, et al., 2014), so cookies with corn syrup would be expected to have lower browning. In addition, cookies made with corn syrup had a lower $\mathrm{pH}$ compared to cookies made with maple syrup and xylitol. These differences accounted for reduced browning and greening and thus lowered the consumption of protein (Table 1; Ames, 1998; Wang, Qian, \& Yao, 2011). The lower protein content in dough made with honey and agave syrup was likely due to the higher fructose and associated protein fructosylation that occurred during preparation and baking (Dills, 1993).

After baking, the water losses in dough were $42,37,32,30$, and $26 \%$ in cookies made with xylitol, corn, agave, maple syrups and honey respectively, resulting in increased protein 
content in cookies compared to dough on the same gram basis. The lower protein content in cookie solutions made with maple syrup and xylitol could be due to the dominant greening reaction in addition to Maillard (Table 1; Dills, 1993; Yabuta, et al., 2001).

\subsubsection{Chlorogenic Acid}

Chlorogenic acid content was similar in doughs. The similar CGA content is because despite CGA existing naturally in honey, maple and agave syrups (Abou-Zaid, Nozzolillo, Tonon, Coppens, \& Lombardo, 2008; Nayik \& Nanda, 2016), it is in lower quantities than that present in the sunflower butter, which was the main contributor of CGA in cookie dough. The CGA decreased in all cookie treatments after baking compared to dough. Chlorogenic acid can be a reactant in Maillard and greening reactions or hydrolyze into caffeic and quinic acids, other phenols and catechol products (Billaud, Roux, Brun-Merimee, Maraschin, \& Nicolas, 2003), causing further losses of free CGA.

Cookies made with xylitol and maple syrup had the lowest CGA content, while cookies made with agave syrup and honey had higher CGA content (Table 4). During baking, free CGA binds with amino groups to form TBA derivatives under alkaline conditions, which explained why cookies made with higher $\mathrm{pH}$ sweeteners (maple syrup and xylitol) turned green soon after baking (Yabuta, et al., 2001).

The decrease in CGA in cookies made with xylitol, maple and agave syrups during $24 \mathrm{~h}$ storage could be caused by free chlorogenic acid continually reacting with primary amino acids and proteins to form TBA derivatives, producing the green color in cookies (Yabuta, et al., 2001). Cookies made with xylitol had the highest $\mathrm{pH}$ and lowest moisture $(P<0.0001)$, but had higher free CGA after 7 days under $84 \%$ RH storage compared to cookies made with maple 
syrup. Xylitol, being a non reducing sugar does not participate in Maillard reactions during baking and this could have accounted for some of the higher free CGA.

The higher moisture content of maple syrup also had a greater effect on greening than the higher $\mathrm{pH}$ of xylitol (Table 1, Fig. 1). The increased greening caused by higher initial moisture content can likewise explain why cookies made with honey had a higher $\mathrm{pH}$ and less \% greening $(P<0.01)$ compared to agave syrup cookies, which had the lowest $\mathrm{pH}$ but more greening (Table 1, Fig. 1).

\subsubsection{Chlorogenic Acid-lysine Adducts and Melanoidins}

The CGA loss due to the different colored reactions were distinguished by quantifying green pigments at $680 \mathrm{~nm}$ and melanoidins at $420 \mathrm{~nm}$. Bongartz et al. (2016) found that when lysine binds to $o$-quinone formed from oxidized chlorogenic acid dimer, the mixture resulted in the highest greening among 20 different amino acids. Lysine's positively charged $\varepsilon$-amino group with a high pKa around 10.5 in polypeptides makes it highly reactive (Mendoza \& Vachet, 2009). The CGA-lysine adduct solutions were thus used to monitor the green pigment production in the present study. Higher moisture and $\mathrm{pH}$ ingredients increased greening in sunflower butter cookies resulting in lower free CGA in cookies made with maple syrup (Fig. 1, Table 1, Table 4). The predominant interaction between $o$-quinone with primary amino acids or side chains from proteins are hydrogen and covalent bonds at alkaline $\mathrm{pH}$. The free CGA, CGA-lysine adducts and greening pigment intensity had correlation coefficient of $-0.9241,0.8738$ and 0.9501 , respectively with greening $\left(-\mathrm{a}^{*}\right)$ in cookies after $0.25 \mathrm{~h}$ of uncovered storage. However, formation of CGA-lysine adducts was not significantly affected by time ( $0.25 \mathrm{~h}$ to $24 \mathrm{~h}$ uncovered storage condition) for all treatments (Table 3), so once adducts formed, the differences over time were minimal. 
Heat accelerates the molecular movement of free CGA and amino groups, and enhances the greening reaction and formation of melanoidins (Bekedam, et al., 2008). Maillard reaction between carbonyls (reducing sugar and CGA) and amino groups from sunflower butter, flour and eggs forms brown melanoidin pigments (Bekedam, et al., 2008). Melanoidin in cookies made with xylitol, corn and agave syrups were not significantly different. Browning was mostly related to the type of sugar in the various formulations Higher glucose content in honey $(\sim 49 \%)$ could explain the higher $\mathrm{A}_{420}$ of cookies made with honey than cookies made with corn (31\%) and agave (10\%) syrups (Fig. S2- supplementary material; St-Pierre, et al., 2014). The high A $_{420}$, indicative of the Maillard reaction in cookies made with maple syrup, may have been due to sucrose inversion to glucose and fructose to form melanoidins under alkaline conditions or interference from green color of sample solutions (Wang, Qian, \& Yao, 2011). Higher pH may have provided the alkaline conditions to favour binding between anions and nucleophilic carbonyl compounds (Hayase, Kim, \& Kato, 1984).

After baking, cookies had decreased $\mathrm{A}_{294}$ compared to the dough caused by polymerization of Schiff bases to form Amadori products and then browning (Table S1supplementary material; Ajandouz, Tchiakpe, Dalle Ore, Benajiba, \& Puigserver, 2001). Increased $\mathrm{A}_{294}$ from 0.25 to $24 \mathrm{~h}$ after baking indicated that formation of Schiff bases which are intermediate Maillard reaction product continually formed during storage. The higher $\mathrm{A}_{294}$ of dough and cookies made with honey and agave syrup during the $24 \mathrm{~h}$ storage, was due to their higher reducing sugar content. The lowest ratio of $\mathrm{A}_{294} / \mathrm{A}_{420}$ in cookies made with maple syrup, was indicative of formation of the least brown colored polymers during baking (Table S1 supplementary material; Chen \& Kitts, 2011) in favour of the green pigments. 


\subsubsection{LC-MS Analysis of Cookie Solutions}

After cyclization of CGA quinone and amino groups, a trihydroxy benzacridine derivative (TBA) core structure forms which has a $m / z$ of 700 . When the TBA core structure binds with lysine, the $\mathrm{m} / \mathrm{z}$ is 829 . Trihydroxy benzacridine derivatives and TBA-lysine both result in green color. Cookies made with maple syrup had a higher mass spectrum intensity at $\mathrm{m} / \mathrm{z} 700$ than cookies made with honey when compared at the same storage time (Fig. 2b-e). The higher intensity of TBA compounds $(\mathrm{m} / \mathrm{z}, 700)$ in cookies made with maple syrup than cookies made with honey was due to more greening adducts formed due to the higher initial moisture and pH of the maple sweetener used (Fig. 2, Yabuta, et al., 2001).

The CGA-lysine standards formed several ions such as: $m / z$ 147, 191, 353, 371, 527, and 700 some of which correspond to lysine (146 g/mol), quinic acid (192 g/mol), CGA (354 g/mol), CGA with a water molecule attached (371), and TBA derivative-dehydrated quinic acid (526 g/mol) (Fig. 2, Table S2-supplementary material, Bongartz et al. 2016). Amongst cookie solutions, besides the greening adducts $(\mathrm{m} / \mathrm{z}, 700)$ and $\mathrm{CGA}+\mathrm{H}_{2} \mathrm{O}(\mathrm{m} / \mathrm{z}, 371)$, there were several ions with $m / z, 119,143,184,445,548$, and 559, which could correspond to threonine (119 $\mathrm{g} / \mathrm{mol}$ ), or other fragments from the Maillard reaction (Schwarzenbolz, Hofmann, Sparmann, \& Henle, 2016; Cerny \& Guntz-Dubini, 2013).

The fragmentation of CGA-lysine adducts $\left(\mathrm{m} / z\right.$, $\left.829[\mathrm{M}+\mathrm{H}]^{+}\right)$and the greening TBA derivative $\left(m / z \quad 700[\mathrm{M}+\mathrm{H}]^{+}\right)$produced several ions: $\mathrm{m} / \mathrm{z} 130(36.51 \%), 147(100 \%), 191$ (37.11\%), 293 (40.63\%), 527 (8.37\%) and 611 (8.31\%) (Table S2-supplementary material). The cookies made with honey had more fragments than cookies made with maple syrup. The main fragments in cookies with honey had $m / z, 127,163,259,289,325,343,487,505$ and 738, while cookies made with maple syrup had 143, 262, 308, 355, 559 and 682 (Fig. S3, Table S2- 
supplementary material). The $\mathrm{m} / \mathrm{z} 163,487$ and 738 fragments in cookies made with honey were possibly Maillard reaction products (Golon, Kropf, Vockenroth, \& Kuhnert, 2014; Zhang, Ames, Smith, Baynes, \& Metz, 2009). The greater Maillard reaction in cookies made with honey was attributed to the higher reducing sugar in honey compared to the greening reaction products found in cookies made with maple syrup due to maple syrup's higher initial moisture and $\mathrm{pH}$ (Yabuta, et al, 2001). The cookies made with maple syrup however had more fragments from TBA derivatives, such as $\mathrm{m} / z 262$ and 308 similar to masses of CGA-lysine adducts found by Bongartz et al.(2016).

Chromatograms of CGA-lysine adduct standard, CGA control, and cookies made with maple syrup and honey, representing highest and lowest greening intensity amongst treatments with two storage conditions ( $24 \mathrm{~h}$ uncovered and $84 \% \mathrm{RH}$ for 7 days storage; Fig. 1, Fig. S1) are presented in Fig. S3. Quinic, chlorogenic, and caffeic acid had retention time of 7.43, 10.38, and 11.22 min respectively (Fig. S3b-supplementary material). The quinic and caffeic acid were hydrolysis products from CGA formed during incubation (Bekedam, Schols, Van Boekel, \& Smit, 2008). The CGA content was higher in the cookies made with honey compared to those made with maple syrup, consistent with results in section 3.3.2. (Table 4). Higher CGA in cookies made with honey was attributed to lower moisture content and $\mathrm{pH}$ which slowed down the color reaction and left more reactants (Prigent, et al., 2008; Yabuta, et al., 2001). With time, CGA content decreased. Cookies made with maple syrup and honey after 7 days storage under 84\% RH condition had less CGA but higher CGA-lysine adducts content than those of $24 \mathrm{~h}$ uncovered storage, which indicated that as CGA decreased, the CGA-lysine adducts, a marker of the greening reaction increased during storage (Table 4, Fig.S3-supplementary material). The lower CGA content in cookies made with maple syrup than cookies made with honey indicated 
that greening in cookies regardless of storage conditons may have occurred from the higher initial moisture and pH when maple syrup was used (Yabuta, et al., 2001).

\section{Conclusions}

Use of sunflower butter as a potential replacement for plant based butters can be hampered by the greening that forms when high $\mathrm{pH}$ conditions are used in baking. The present study shows that selection of sweeteners should be considered when using sunflower butter in baking due to their effect on greening induced by CGA-protein interactions. The higher CGA in cookies made with honey stemmed from the lower $\mathrm{pH}$ values that decreased CGA-lysine adduct formation compared to those made with maple syrup. The cookies made with sweeteeners that had higher initial moisture and $\mathrm{pH}$ had less free CGA and CGA-lysine adducts formed due to the consumption of CGA in the greening reaction. The higher moisture and $\mathrm{a}_{\mathrm{w}}$ may have increased the molecular movement of reactants resulting in higher \% greening and greening intensity. Our findings thus suggest that lower greening can be obtained by use of low $\mathrm{pH}$ and low moisture sweeteners such as honey, while higher greening can be achieved by use of high $\mathrm{pH}$ and moisture sweeteners such as maple syrup. Given that consumer acceptance of foods is influenced by color, controlling this greening would enable the use of sunflower butter as a replacement for peanut and other tree nut butters in baking for those with allergies to these nuts. Selection of sweeteners used for baking in addition to control of humidity conditions is suggested as a way to control surface greening. Further studies should focus on quantifying how much chlorogenic acid acts as a reactant in browning versus greening reactions and their associated effects on nutrition.

\section{Acknowledgements}

This research was financially supported in part by a grant from the National Science Foundation, Division of Earth Sciences, NSF-EAR \#1359500 and Chapman University. The 
authors would like to thank Dr. Aftab Ahmed for his assistance with LC/MS and Irving Vargas

with the preliminary data collection.

\section{Conflict of Interest}

Authors do not have any conflict of interest

\section{References}

AACCI. (1999a). AACC International Approved Methods, Method 02-52.01. Hydrogen-Ion Activity (pH) -- Electrometric Method. In 11th ed.). St. Paul, MN, U.S.A.

AACCI. (1999b). AACC International Approved Methods, Method 10-50.05. Baking Quality of Cookie Flour. In 11th ed.). St. Paul, MN, U.S.A.

Abou-Zaid, M. M., Nozzolillo, C., Tonon, A., Coppens, M., \& Lombardo, D. A. (2008). Highperformance liquid chromatography characterization and identification of antioxidant polyphenols in maple syrup. Pharmaceutical Biology, 46, 117-125.

Ajandouz, E. H., Tchiakpe, L. S., Dalle Ore, F., Benajiba, A., \& Puigserver, A. (2001). Effects of $\mathrm{pH}$ on caramelization and Maillard reaction kinetics in fructose-lysine model systems. Journal of Food Science, 66, 926-931.

Ames, J. M. (1998). Applications of the Maillard reaction in the food industry. Food Chemistry, $62,431-439$.

AOAC (2005). Method 925.09, Official Methods of Analysis of AOAC International, Moisture Content in Flour and Flour Mixes.

Ball, D. W. (2007). The chemical composition of honey and maple syrup. Journal of Chemical Education, 84, 1643-1650.

Bekedam, E. K., Schols, H. A., Van Boekel, M. A. J. S., \& Smit, G. (2008). Incorporation of chlorogenic acids in coffee brew melanoidins. Journal of Agricultural and Food Chemistry, 56, 2055-2063.

Billaud, C., Roux, E., Brun-Merimee, S., Maraschin, C., \& Nicolas, J. (2003). Inhibitory effect of unheated and heated D-glucose, D-fructose and L-cysteine solutions and Maillard reaction product model systems on polyphenoloxidase from apple. I. Enzymatic browning and enzyme activity inhibition using spectrophotometric and polarographic methods. Food Chemistry, 81, 35-50.

Bongartz, V., Brandt, L., Gehrmann, M. L., Zimmermann, B. F., Schulze-Kaysers, N., \& Schieber, A. (2016). Evidence for the Formation of Benzacridine Derivatives in AlkalineTreated Sunflower Meal and Model Solutions. Molecules, 21, 91.

Cauvain, S. P., \& Young, L. S. (2008). Stategies for Extending Bakery Product Shelf-life. In Bakery Food Manufacture and Quality: Water Control and Effects 2 ed., (pp. 271-272). BakeTran, High Wycombe, Buckinghamshire, UK: Wiley-Blackwell Publishing.

Cerny, C., \& Guntz-Dubini, R. (2013). Formation of cysteine-S-conjugates in the Maillard reaction of cysteine and xylose. Food Chemistry, 141(2), 1078-1086. 
Chen, X. M., \& Kitts, D. D. (2011). Correlating Changes That Occur in Chemical Properties with the Generation of Antioxidant Capacity in Different Sugar-Amino Acid Maillard Reaction Models. Journal of Food Science, 76, C831-C837.

Dills, W. L. (1993). Protein Fructosylation: Fructose and The Maillard Reaction. American Journal of Clinical Nutrition, 58, 779-787.

FDA (US Food and Drug Administration). Food Allergies: What You Need to Know, 2016 URL https://www.fda.gov/downloads/Food/ResourcesForYou/Consumers/UCM220117.pdf Accessed 30.11.16.

Fradinho, P., Cristiana Nunes, M., \& Raymundo, A. (2015). Developing consumer acceptable biscuits enriched with Psyllium fibre. Journal of Food Science and Technology-Mysore, 52, 4830-4840.

Gokmen, V., Acar, O. C., Serpen, A., \& Morales, F. J. (2008). Effect of leavening agents and sugars on the formation of hydroxymethylfurfural in cookies during baking. European Food Research and Technology, 226(5), 1031-1037.

Golon, A., Kropf, C., Vockenroth, I., \& Kuhnert, N. (2014). An Investigation of the Complexity of Maillard Reaction Product Profiles from the Thermal Reaction of Amino Acids with Sucrose Using High Resolution Mass Spectrometry. Foods (Basel, Switzerland), 3, 461475.

Hawkins, C. L., Morgan, P. E., \& Davies, M. J. (2009). Quantification of protein modification by oxidants. Free Radical Biology and Medicine, 46, 965-988.

Hayase, F., Kim, S. B., \& Kato, H. (1984). Decolorization and Degradation Products of the Melanoidins by Hydrogen Peroxide. Agricultural and Biological Chemistry, 48, 27112717.

Ishak, W. I. W., \& Hudzari, R. M. (2010). Image based modeling for oil palm fruit maturity prediction. Journal of Food Agriculture \& Environment, 8, 469-476.

Jully, K.M.M., Toto, C.S., \& Were, L. (2016). Antioxidant effect of spent, ground, and lyophilized brew from roasted coffee in frozen cooked pork patties. LWT-Food Science and Technology, 244-251.

Lima, I. M., \& Guraya, H. S. (2005). Optimization analysis of sunflower butter. Journal of Food Science, 70, S365-S370.

Mendoza, V. L., \& Vachet, R. W. (2009). Probing Protein Structure by Amino Acid-Specific Covalent Labeling and Mass Spectrometry. Mass spectrometry reviews, 28, 785-815.

Miller, R. A., Graf, E., \& Hoseney, R. C. (1994). Leavened Dough pH Determination by an Improved Method. Journal of Food Science, 59, 1086-1090.

Nayik, G. A., \& Nanda, V. (2016). A chemometric approach to evaluate the phenolic compounds, antioxidant activity and mineral content of different unifloral honey types from Kashmir, India. LWT-Food Science and Technology, 74, 504-513.

NPI (Nutrual Products Insider). Nut Butter, Sweet Spread Sector to Hit \$6.5 Billion by 2018, 2014. URL http://www.naturalproductsinsider.com/news/2014/04/nut-butter-sweetspread-sector-to-hit-6-5-billion.aspx Accessed 02.10.17.

Peabody, E. Sunflower seed "butter" improves as it spreads across America, 2016. URL https://www.ars.usda.gov/news-events/news/research-news/2005/sunflower-seed-butterimproves-as-it-spreads-across-america/ Accessed 17.05.17.

Prigent, S. V. E., Voragen, A. G. J., Li, F., Visser, A. J. W. G., van Koningsveld, G. A., \& Gruppen, H. (2008). Covalent interactions between amino acid side chains and oxidation 
products of caffeoylquinic acid (chlorogenic acid). Journal of the Science of Food and Agriculture, 88, 1748-1754.

Schwarzenbolz, U., Hofmann, T., Sparmann, N., \& Henle, T. (2016). Free Maillard Reaction Products in Milk Reflect Nutritional Intake of Glycated Proteins and Can Be Used to Distinguish "Organic" and "Conventionally" Produced Milk. Journal of Agricultural and Food Chemistry, 64(24), 5071-5078.

Serna-Saldivar, S. O. (2012). Production of Chemical-Leavened Products: Cookies, Cakes, and Related Products, Donuts, and wheat Flour Tortillas. In Cereal grains: laboratory reference and procedures manual, (pp. 251-254): CRC Press.

Silva, P. M. d., Gauche, C., Gonzaga, L. V., Costa, A. C. O., \& Fett, R. (2016). Honey: chemical composition, stability and authenticity. Food Chemistry, 196, 309-323.

St-Pierre, P., Pilon, G., Dumais, V., Dion, C., Dubois, M. J., Dube, P., Desjardins, Y., \& Marette, A. (2014). Comparative analysis of maple syrup to other natural sweeteners and evaluation of their metabolic responses in healthy rats. Journal of Functional Foods, 11, 460-471.

Suas, M. (2009). Pastry. In M. Suas (Ed.), Advanced Bread and Pastry 1st. ed., (pp. 411-412). New York, USA: Delmar, Cengage Learning.

Vaintraub, I. A., \& Kratch, V. V. (1989). Changes in Free and Boundchlorogenic Acid and in Polyphenoloxidase Activity during the Industrial Processing of Sunflower Seeds. Nahrung-Food, 33, 95-97.

Wang, Qian, H., \& Yao, W.-R. (2011). Melanoidins produced by the Maillard reaction: Structure and biological activity. Food Chemistry, 128, 573-584.

Weisz, G. M., Kammerer, D. R., \& Carle, R. (2009). Identification and quantification of phenolic compounds from sunflower (Helianthus annuus L.) kernels and shells by HPLCDAD/ESI-MS ${ }^{\mathrm{n}}$. Food Chemistry, 115, 758-765.

Yabuta, G., Koizumi, Y., Namiki, K., Hida, M., \& Namiki, M. (2001). Structure of green pigment formed by the reaction of caffeic acid esters (or chlorogenic acid) with a primary amino compound. Bioscience Biotechnology and Biochemistry, 65, 2121-2130.

Zhang, Ames, J. M., Smith, R. D., Baynes, J. W., \& Metz, T. O. (2009). A Perspective on the Maillard Reaction and the Analysis of Protein Glycation by Mass Spectrometry: Probing the Pathogenesis of Chronic Disease. Journal of proteome research, 8, 754-769.

Zhang, L., Nishizu, T., Kishigami, H., Kato, A., \& Goto, K. (2013). Measurement of internal shrinkage distribution in spaghetti during drying by X-ray microCT. Food Research International, 51, 180-187. 


\section{Figure Captions}

Fig. 1. Greening changes in cookies made with sunflower butter as a function of time and sweetener used. Hunter "a" greening (-a*) of upper (a), bottom (b), internal (c) and \% internal greening $(\mathrm{d})$ of cookies during $24 \mathrm{~h}$ of uncovered storage.

Fig. 2. Mass spectrometric fragments of standards (chlorogenic acid-lysine adducts, chlorogenic acid) and cookies made with maple syrup and honey after $24 \mathrm{~h}$ of uncovered storage and 7 days under $84 \%$ RH condition. TBA: trihydroxy benzacridine derivatives, MRPs: Maillard reaction products

fragments. 


\section{Figures}

a) Upper greening in cookies

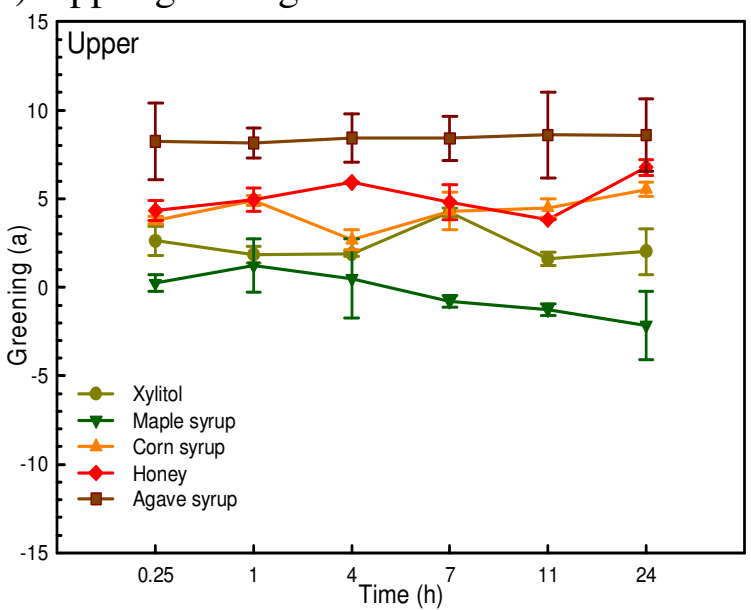

c) Internal greening of cookies

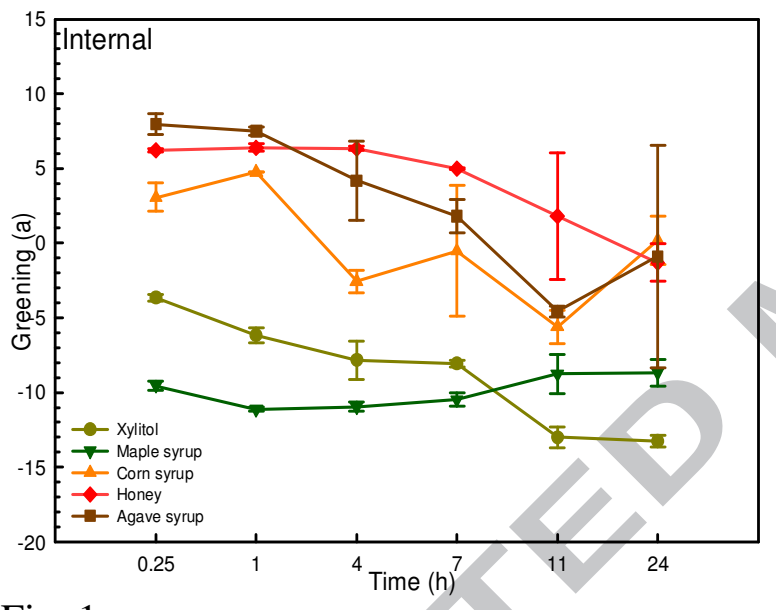

Fig. 1. b) Bottom greening in cookies

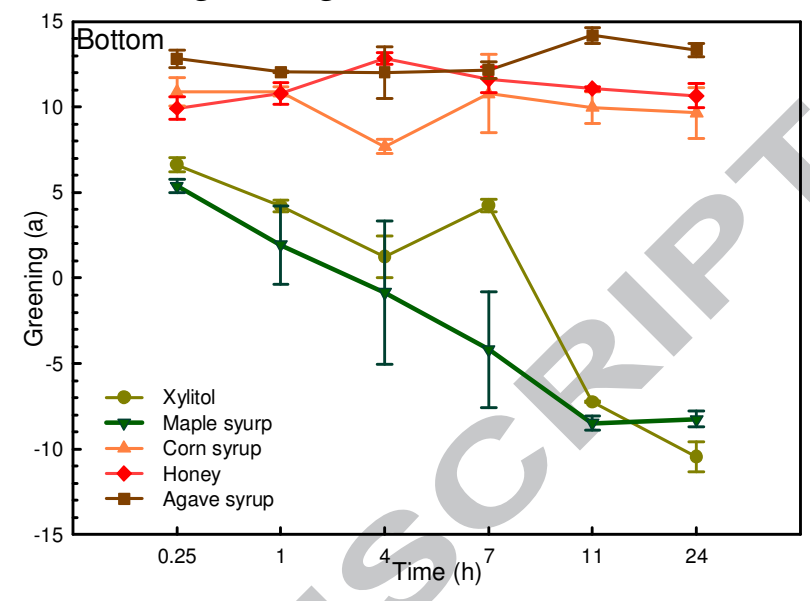

d) $\%$ Internal greening of cookies

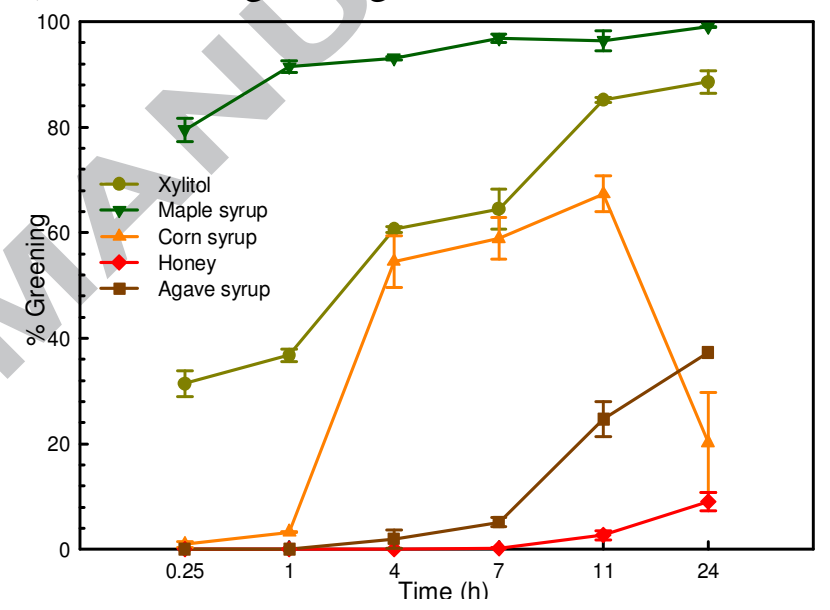


a) Chlorogenic acid-lysine adducts standard

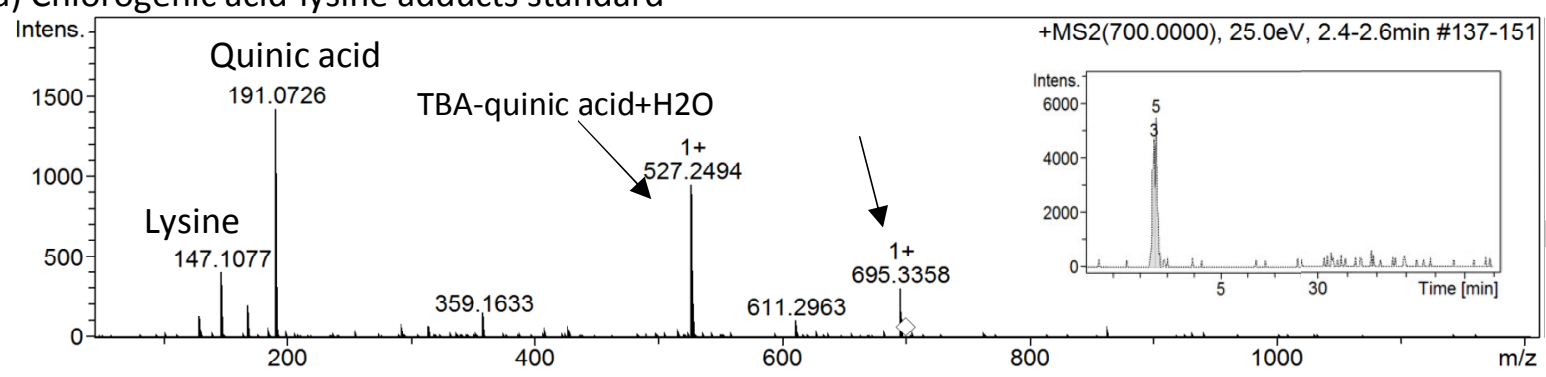

b) Cookies made with honey after $24 \mathrm{~h}$ uncovered storage

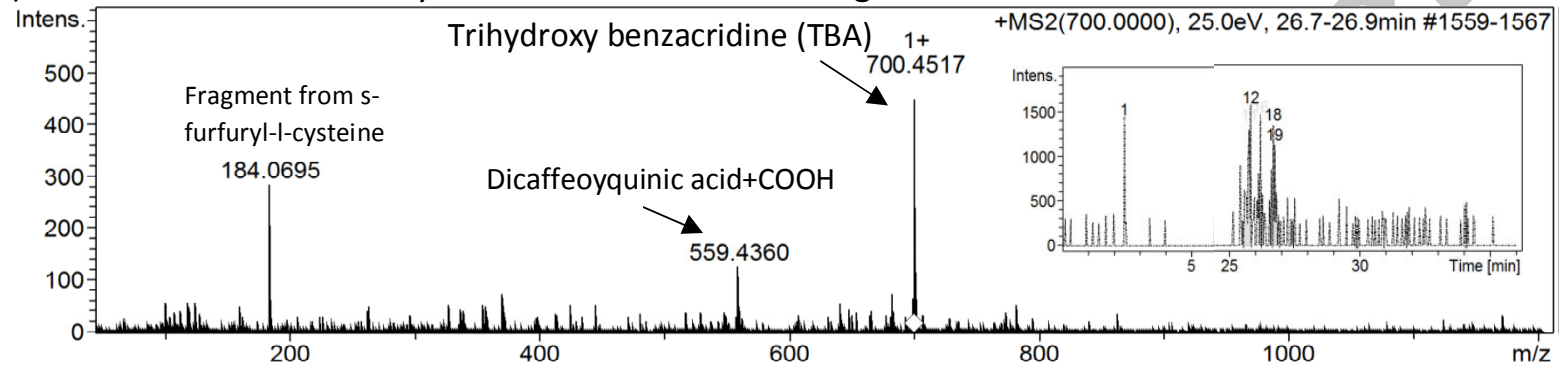

c) Cookies made with maple syrup after $24 \mathrm{~h}$ uncovered storage

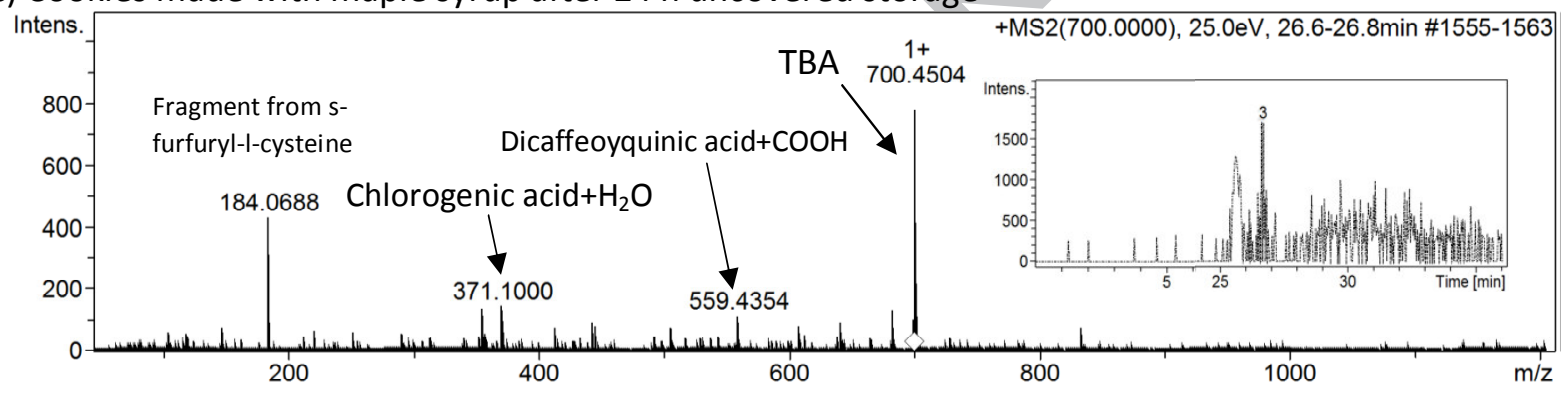

d) Cookies made with honey after 7 days under $84 \% \mathrm{RH}$ storage

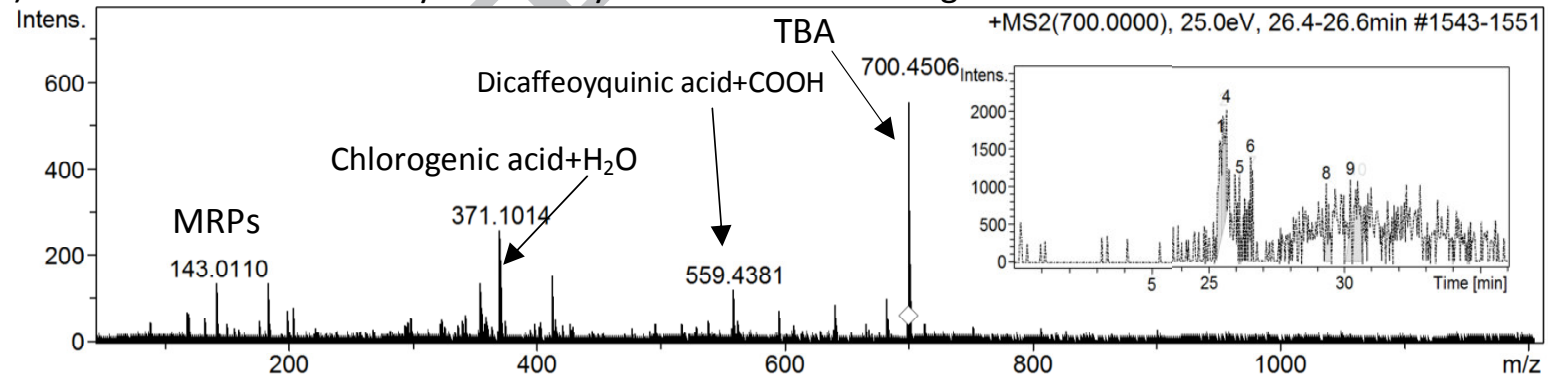

e) Cookies made with maple syrup after 7 days under $84 \%$ RH storage (TIC+MS2: 700.0000)

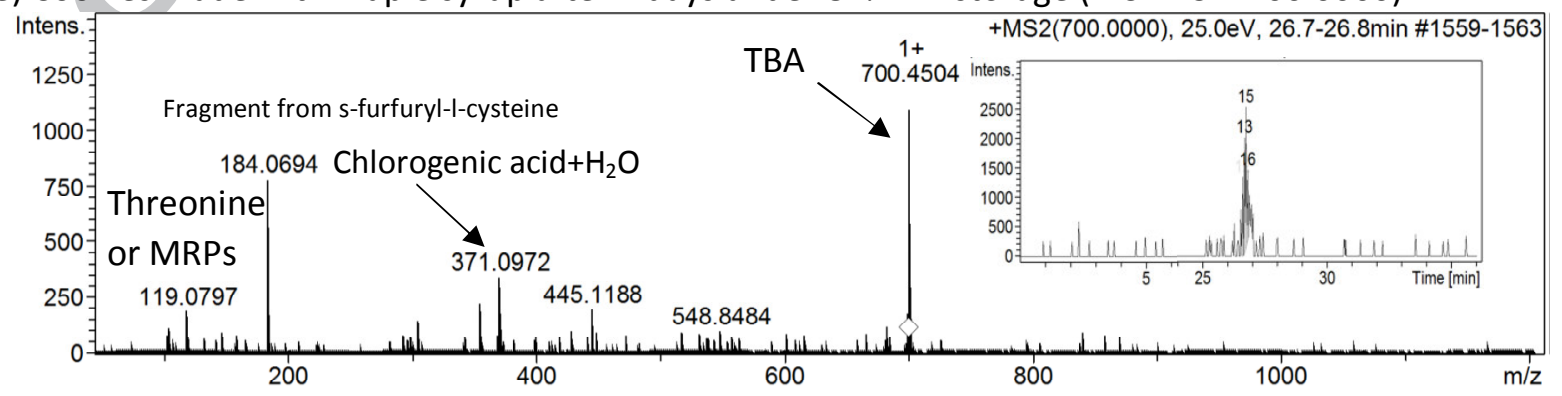

Fig. 2. 


\section{Tables}

Table 1. pH, spread factor, moisture and protein content of dough and cookies

\begin{tabular}{|c|c|c|c|c|c|c|}
\hline \multirow[t]{2}{*}{ Treatment } & \multicolumn{4}{|c|}{ pH } & \multicolumn{2}{|c|}{ Spread factor } \\
\hline & $\begin{array}{l}\text { Sweeteners } \\
\text { solution } \dagger\end{array}$ & Dough $\dagger$ & $\begin{array}{l}\text { Cookie } \dagger \\
(0.25 \text { h })\end{array}$ & $\begin{array}{l}\text { Cookie } \dagger \\
(24 \mathrm{~h})\end{array}$ & Dough & $\begin{array}{l}\text { Cookie } \\
(0.25 h)\end{array}$ \\
\hline Maple syrup & $6.28 \pm 0.115^{\mathrm{a}^{1}}$ & $7.57 \pm 0.05^{\mathrm{ab}}$ & $8.99 \pm 0.01^{b}$ & $8.94 \pm 0.02^{\mathrm{ab}}$ & $3.05^{\mathrm{b}}$ & $2.05^{\mathrm{b}}$ \\
\hline Xylitol & $6.12 \pm 0.045^{\mathrm{a}}$ & $7.66 \pm 0.03^{\mathrm{a}}$ & $9.13 \pm 0.01^{\mathrm{a}}$ & $9.05 \pm 0.02^{\mathrm{a}}$ & $5.08^{\mathrm{a}}$ & $2.88^{\mathrm{a}}$ \\
\hline Corn syrup & $4.76 \pm 0.005^{\mathrm{b}}$ & $7.62 \pm 0.01^{\mathrm{ab}}$ & $8.69 \pm 0.05^{\mathrm{c}}$ & $8.42 \pm 0.02^{\mathrm{ab}}$ & $5.06^{\mathrm{a}}$ & $2.59^{\mathrm{ab}}$ \\
\hline Agave syrup & $4.49 \pm 0.035^{\mathrm{c}}$ & $7.55 \pm 0.03^{\mathrm{ab}}$ & $8.44 \pm 0.04^{\mathrm{d}}$ & $8.30 \pm 0.03^{\mathrm{ab}}$ & $4.71^{\mathrm{a}}$ & $3.00^{\mathrm{ab}}$ \\
\hline Honey & $3.93 \pm 0.035^{\mathrm{d}}$ & $7.52 \pm 0.04^{b}$ & $8.63 \pm 0.02^{c}$ & $8.41 \pm 0.05^{\mathrm{b}}$ & $4.40^{\mathrm{a}}$ & $2.43^{\mathrm{ab}}$ \\
\hline \multirow[t]{2}{*}{ Treatment } & \multicolumn{3}{|c|}{ Moisture (\%) } & \multicolumn{3}{|c|}{ Protein content (mg/g wet basis) } \\
\hline & Sweeteners & Dough & Cookie & Dough & $\begin{array}{l}\text { Cookie } \\
(0.25 h)\end{array}$ & $\begin{array}{l}\text { Cookie } \\
(24 h)\end{array}$ \\
\hline Maple syrup & $32.40 \pm 0.017^{\mathrm{a}}$ & $19.96 \pm 0.00^{\mathrm{a}}$ & $14.06 \pm 0.00^{\mathrm{a}}$ & $12.20 \pm 0.42^{b}$ & $11.82 \pm 1.11^{\mathrm{bc}}$ & $26.10 \pm 2.93^{\mathrm{bc}}$ \\
\hline Xylitol & $12.05 \pm 0.000^{\mathrm{d}}$ & $15.44 \pm 0.00^{\mathrm{b}}$ & $8.97 \pm 0.00^{\mathrm{d}}$ & $11.30 \pm 0.18^{b c}$ & $15.00 \pm 1.25^{\mathrm{ab}}$ & $35.91 \pm 4.25^{\mathrm{ab}}$ \\
\hline Corn syrup & $22.06 \pm 0.008^{b}$ & $18.02 \pm 0.00^{\mathrm{ab}}$ & $11.34 \pm 0.00^{c}$ & $21.93 \pm 1.34^{\mathrm{a}}$ & $16.51 \pm 0.86^{\mathrm{a}}$ & $37.64 \pm 2.03^{\mathrm{a}}$ \\
\hline Agave syrup & $23.45 \pm 0.015^{b}$ & $17.90 \pm 0.00^{\mathrm{ab}}$ & $12.09 \pm 0.00^{b}$ & $8.95 \pm 0.26^{\mathrm{c}}$ & $9.76 \pm 1.13^{\mathrm{c}}$ & $23.85 \pm 0.19^{c}$ \\
\hline Honey & $13.56 \pm 0.016^{\mathrm{c}}$ & $15.49 \pm 0.02^{\mathrm{b}}$ & $11.45 \pm 0.00^{\mathrm{c}}$ & $9.28 \pm 0.31^{\mathrm{c}}$ & $10.49 \pm 0.36^{\mathrm{c}}$ & $34.38 \pm 2.08^{\mathrm{ab}}$ \\
\hline $\begin{array}{l}\text { Values are th } \\
\text { same letters } \\
\text { Concentrati }\end{array}$ & verage of fo & eplicates fror & $\mathrm{n}$ four differer & cookies \pm sta & dard deviation & 10 , and \\
\hline
\end{tabular}


Table 2. Water activity $\left(\mathrm{a}_{\mathrm{w}}\right)$ of cookies after baking and storage.

\begin{tabular}{|c|c|c|c|c|c|c|}
\hline $\begin{array}{l}\text { Storage } \\
\text { conditions }\end{array}$ & $\begin{array}{l}\text { Sweeteners } \\
\text { Time (h) }\end{array}$ & Maple syrup & Xylitol & Corn syrup & Agave syrup & Honey \\
\hline \multirow{7}{*}{ Uncovered } & 0.25 & $0.798 \pm 0.01^{\mathrm{a}}$ & $0.535 \pm 0.00^{\mathrm{d}}$ & $0.672 \pm 0.00^{c}$ & $0.694 \pm 0.01^{\mathrm{bc}}$ & $0.712 \pm 0.01^{\mathrm{b}}$ \\
\hline & 1 & $0.827 \pm 0.01^{\mathrm{a}}$ & $0.579 \pm 0.01^{\mathrm{c}}$ & $0.695 \pm 0.02^{\mathrm{b}}$ & $0.687 \pm 0.00^{\mathrm{b}}$ & $0.666 \pm 0.02^{b}$ \\
\hline & 4 & $0.708 \pm 0.01^{\mathrm{a}}$ & $0.526 \pm 0.00^{c}$ & $0.657 \pm 0.02^{\mathrm{b}}$ & $0.637 \pm 0.01^{\mathrm{b}}$ & $0.630 \pm 0.01^{\mathrm{b}}$ \\
\hline & 7 & $0.731 \pm 0.00^{\mathrm{a}}$ & $0.535 \pm 0.01^{\mathrm{d}}$ & $0.620 \pm 0.01^{\mathrm{c}}$ & $0.642 \pm 0.00^{\mathrm{b}}$ & $0.643 \pm 0.00^{\mathrm{b}}$ \\
\hline & 11 & $0.719 \pm 0.01^{\mathrm{a}}$ & $0.539 \pm 0.00^{c}$ & $0.611 \pm 0.00^{\mathrm{b}}$ & $0.621 \pm 0.02^{\mathrm{b}}$ & $0.608 \pm 0.00^{\mathrm{b}}$ \\
\hline & 24 & $0.664 \pm 0.00^{\mathrm{a}}$ & $0.520 \pm 0.01^{\mathrm{d}}$ & $0.532 \pm 0.01^{\mathrm{cd}}$ & $0.597 \pm 0.03^{b}$ & $0.583 \pm 0.01^{\mathrm{bc}}$ \\
\hline & \multicolumn{4}{|l|}{ Time (day) } & -1 & \\
\hline \multirow{3}{*}{$75 \% \mathrm{RH}$} & 1 & $0.802 \pm 0.00^{\mathrm{a}}$ & $0.666 \pm 0.00^{\mathrm{d}}$ & $0.754 \pm 0.00^{c}$ & $0.759 \pm 0.02^{\mathrm{b}}$ & $0.761 \pm 0.00^{\mathrm{b}}$ \\
\hline & 4 & $0.749 \pm 0.02^{\mathrm{a}}$ & $0.629 \pm 0.01^{\mathrm{e}}$ & $0.663 \pm 0.02^{\mathrm{d}}$ & $0.740 \pm 0.00^{\mathrm{b}}$ & $0.737 \pm 0.01^{\mathrm{c}}$ \\
\hline & 7 & $0.714 \pm 0.02^{\mathrm{a}}$ & $0.597 \pm 0.02^{\mathrm{c}}$ & $0.589 \pm 0.02^{\mathrm{d}}$ & $0.663 \pm 0.00^{\mathrm{b}}$ & $0.715 \pm 0.00^{\mathrm{a}}$ \\
\hline \multirow{3}{*}{$79 \%$ RH } & 1 & $0.833 \pm 0.00^{\mathrm{a}}$ & $0.693 \pm 0.01^{\mathrm{d}}$ & $0.751 \pm 0.02^{\mathrm{c}}$ & $0.751 \pm 0.01^{\mathrm{c}}$ & $0.770 \pm 0.01^{\mathrm{b}}$ \\
\hline & 4 & $0.793 \pm 0.01^{\mathrm{a}}$ & $0.668 \pm 0.00^{e}$ & $0.715 \pm 0.02^{\mathrm{d}}$ & $0.756 \pm 0.01^{\mathrm{b}}$ & $0.738 \pm 0.01^{\mathrm{c}}$ \\
\hline & 7 & $0.737 \pm 0.04^{\mathrm{a}}$ & $0.643 \pm 0.03^{\mathrm{d}}$ & $0.739 \pm 0.02^{\mathrm{a}}$ & $0.681 \pm 0.02^{\mathrm{b}}$ & $0.675 \pm 0.01^{\mathrm{c}}$ \\
\hline \multirow{3}{*}{$84 \%$ RH } & 1 & $0.815 \pm 0.01^{\mathrm{a}}$ & $0.708 \pm 0.01^{\mathrm{d}}$ & $0.810 \pm 0.01^{\mathrm{b}}$ & $0.745 \pm 0.01^{\mathrm{c}}$ & $0.746 \pm 0.01^{\mathrm{c}}$ \\
\hline & 4 & $0.794 \pm 0.01^{\mathrm{a}}$ & $0.695 \pm 0.01^{\mathrm{e}}$ & $0.756 \pm 0.01^{\mathrm{b}}$ & $0.722 \pm 0.00^{\mathrm{d}}$ & $0.727 \pm 0.01^{\mathrm{c}}$ \\
\hline & 7 & $0.741 \pm 0.00^{\mathrm{a}}$ & $0.695 \pm 0.01^{\mathrm{e}}$ & $0.737 \pm 0.00^{\mathrm{b}}$ & $0.719 \pm 0.01^{\mathrm{c}}$ & $0.714 \pm 0.01^{\mathrm{d}}$ \\
\hline
\end{tabular}

Values are the average of four replicates \pm standard deviation.

Same letters in each row are not significantly different $(P>0.05)$. 
Table 3. General linear model effect and interaction of different sweeteners, humidity conditions, and storage time on greening intensity and greening reaction reactants and products

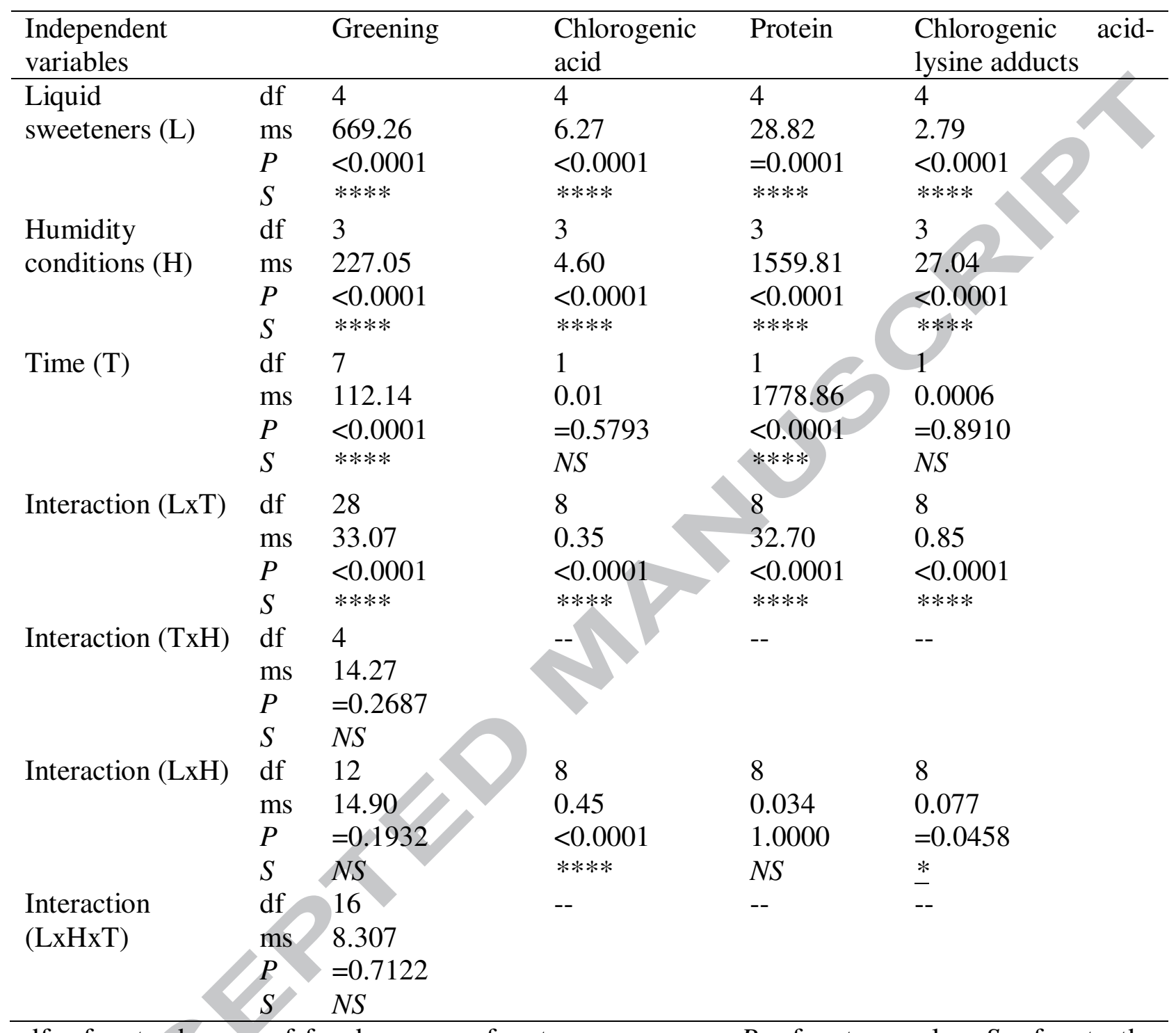

df refers to degrees of freedom, ms refers to mean square, $P$ refers to p value, $S$ refers to the significant level: $* * * *$ refers to very significant; * refers to significant $(P<0.5), N S$ refers to not significant. 
Table 3. Chlorogenic acid (mg/g) and chlorogenic acid-lysine adducts (mg/g) in dough and cookies made with various sweeteners.

\section{Cookie}

\begin{tabular}{|c|c|c|c|c|c|c|}
\hline Sweeteners & Dough (2 h) & $\begin{array}{l}\text { After baking } \\
(0.25 \mathrm{~h})\end{array}$ & $\begin{array}{l}\text { After baking } \\
(24 \mathrm{~h})\end{array}$ & $\begin{array}{l}75 \% \text { RH } \\
\text { (7 days) }\end{array}$ & $\begin{array}{l}79 \% \text { RH (7 } \\
\text { days) }\end{array}$ & $\begin{array}{l}\text { 84\% RH } \\
\text { (7 days) }\end{array}$ \\
\hline \multicolumn{7}{|c|}{ Chlorogenic acid (mg/g) quantified using HPLC } \\
\hline Maple syrup & $2.60 \pm 0.046^{\mathrm{a}}$ & $0.49 \pm 0.032^{\mathrm{c}}$ & $0.28 \pm 0.003^{\mathrm{c}}$ & $0.85 \pm 0.098^{\mathrm{c}}$ & $0.58 \pm 0.022^{\mathrm{c}}$ & $0.37 \pm 0.000^{c}$ \\
\hline Xylitol & $2.60 \pm 0.068^{\mathrm{a}}$ & $0.44 \pm 0.070^{\mathrm{c}}$ & $0.34 \pm 0.105^{\mathrm{c}}$ & $0.91 \pm 0.003^{\mathrm{c}}$ & $0.77 \pm 0.093^{\mathrm{c}}$ & $0.78 \pm 0.049^{b}$ \\
\hline Corn syrup & $2.65 \pm 0.016^{\mathrm{a}}$ & $0.99 \pm 0.048^{\mathrm{b}}$ & $1.00 \pm 0.063^{\mathrm{b}}$ & $2.31 \pm 0.057^{\mathrm{b}}$ & $1.64 \pm 0.247^{\mathrm{b}}$ & $1.05 \pm 0.061^{\mathrm{b}}$ \\
\hline Agave syrup & $2.68 \pm 0.041^{\mathrm{a}}$ & $1.39 \pm 0.017^{\mathrm{a}}$ & $1.27 \pm 0.065^{\mathrm{a}}$ & $3.08 \pm 0.594^{\mathrm{b}}$ & $2.40 \pm 0.047^{\mathrm{a}}$ & $1.95 \pm 0.205^{\mathrm{a}}$ \\
\hline Honey & $2.72 \pm 0.037^{\mathrm{a}}$ & $1.31 \pm 0.136^{\mathrm{a}}$ & $1.45 \pm 0.054^{\mathrm{a}}$ & $4.35 \pm 0.028^{\mathrm{a}}$ & $2.44 \pm 0.136^{\mathrm{a}}$ & $1.88 \pm 0.008^{\mathrm{a}}$ \\
\hline \multicolumn{7}{|c|}{ Chlorogenic acid-lysine adducts (mg/g) quantified using Absorbance at $680 \mathrm{~nm}$} \\
\hline Maple syrup & $0.40 \pm 0.013$ & $2.40 \pm 0.054^{\mathrm{a}}$ & $3.21 \pm 0.393^{\mathrm{a}}$ & $3.71 \pm 0.036^{\mathrm{a}}$ & $4.04 \pm 0.151^{\mathrm{a}}$ & $4.08 \pm 0.110^{\mathrm{a}}$ \\
\hline Xylitol & bdl & $2.20 \pm 0.071^{\mathrm{ab}}$ & $2.82 \pm 0.079^{\mathrm{ab}}$ & $2.94 \pm 0.183^{b}$ & $2.83 \pm 0.088^{\mathrm{b}}$ & $3.46 \pm 0.141^{\mathrm{ab}}$ \\
\hline Corn syrup & bdl & $2.06 \pm 0.088^{\mathrm{b}}$ & $2.00 \pm 0.135^{\mathrm{bc}}$ & $2.26 \pm 0.083^{\mathrm{c}}$ & $2.64 \pm 0.040^{\mathrm{b}}$ & $2.59 \pm 0.194^{\mathrm{bc}}$ \\
\hline Agave syrup & bdl & & $1.79 \pm 0.191^{\mathrm{cd}}$ & $2.02 \pm 0.160^{\mathrm{cd}}$ & $1.71 \pm 0.109^{c}$ & $1.96 \pm 0.070^{\mathrm{c}}$ \\
\hline Honey & bdl & $1.35 \pm 0.172^{\mathrm{c}}$ & $1.16 \pm 0.358^{\mathrm{d}}$ & $1.72 \pm 0.222^{\mathrm{d}}$ & $2.05 \pm 0.621^{\mathrm{d}}$ & $1.96 \pm 0.522^{\mathrm{c}}$ \\
\hline
\end{tabular}

bdl refers to below detection limit.

Values are the average of four replicates from four different cookies \pm standard deviation.

Same letters in each column of chlorogenic acid and chlorogenic acid-lysine adducts data are not significantly different $(P>0.05)$. 